\title{
Quebec program combats RSV in northern babies
}

\author{
- Cite as: CMAJ 2017 January 23;189:E122. doi: 10.1503/cmaj.109-5368
}

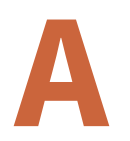

Il Inuit babies born in Nunavik, northern Quebec, will receive injections of palivizumab (Synagis) to protect against respiratory syncytial virus (RSV), a lower respiratory virus they are particularly prone to contracting, under a new Quebec Ministry of Health directive.

The therapy is currently only given to premature babies and those born with life-threatening cardiac or pulmonary conditions.

Up to half the babies born in Nunavik who are admitted to hospital have respiratory tract infections, says Dr. Anna Banerji, a clinical pediatrician and researcher at the University of Toronto. Her latest research, published in CMAJ Open, estimates that 120 babies out of 250 born in 2009 , or $48 \%$, were admitted to hospital, mostly in the Nunavik region, due to RSV.

"Worldwide, it is the number one cause of babies being admitted to hospitals. So there is nothing new about this virus. But what is new is the number - the actual rate of admission in this case - which is the highest ever documented in the world." According to the US Centers for Disease Control and Prevention, most babies contract RSV by two years of age, but fewer than $2 \%$ are admitted to the hospital.

Banerji says Quebec's directive is a positive step toward curbing the high rate of hospital admissions due to RSV in the north.

But the new directive, which came into effect Dec. 1, was a complete surprise for the director of public health in Nunavik. "I was not consulted on this," said Dr. Françoise Bouchard, who has requested a meeting with officials at Quebec's Ministry of Health about the directive. "We have several concerns. For one, this immunoglobulin therapy has never been tested on healthy babies."

Although clinical studies show there are benefits to giving palivizumab to premature babies and those deemed at high risk, she argues that the risk-benefit ratio might not be the same for healthy newborns.

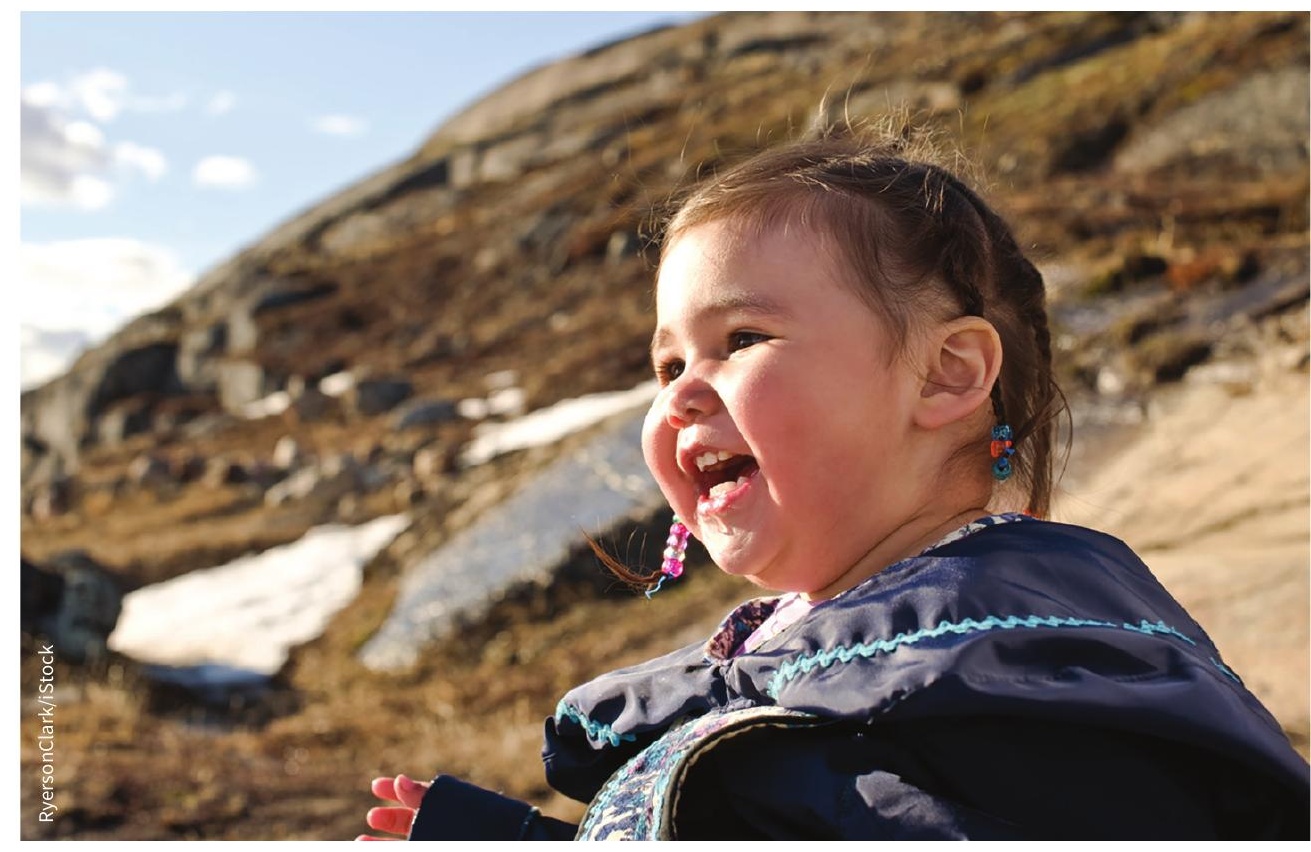

One study estimates that $48 \%$ of babies born in Nunavik in 2009 were admitted to hospital with respiratory syncytial virus.

Bouchard is also concerned about the increased workload the new directive will put on a nursing staff who are already working to capacity.

The new directive requires that every newborn receive injections of palivizumab every month for four or five months. This means nurses will have to deliver hundreds of new shots.

In addition to taxing staff, it will require young parents to make the journey to the hospital every month for their baby's injections, says Nunavik nurse Amélie Drôlet. "It will be difficult to ensure continuity," she says.

Officials also question whether the benefits outweigh the financial costs. Each course of treatment will cost Quebec taxpayers a minimum of $\$ 8000$.

But for Dr. Johanne Morel, a pediatrician at the Montréal Children's Health Hospital, and a consultant in the north, the preventive value of palivizumab makes it well worth the expense - particularly given the high costs of treating the two or three babies each year who are so sick they need to be treated at the Montreal hospital's intensive care unit (ICU).

"It is very expensive to transport a child from the north to Montréal, and admitting a baby to ICU costs tens of thousands of dollars," Morel says. She says immunizing the babies is worth the effort and expense.

Quebec is the first province to immunize healthy infants against the virus. Other regions, such as Nunavut and the Northwest Territories, which also have a high incidence, are discussing the issue but have not yet taken similar steps.

"They probably want to wait and see how this goes in Nunavik," says Morel. "They've asked us to keep a registry for evaluation."

Immunizations will run until May 1 , 2017. It is recommended the measure be re-evaluated annually.

Véronique Morin, Montréal, Que. 